심방조동

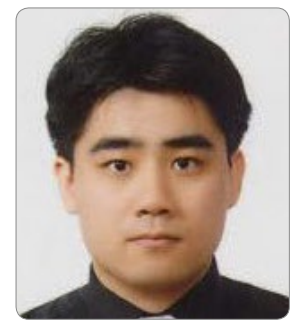

이찬희

영남대학교 의과대학 내과학교실

Chan-Hee Lee, MD

Division of Cardiology, Yeungnam University Medical Center, Daegu, Republic of Korea

Received: April 22, 2016

Accepted: October 5, 2016

Correspondence: Chan-Hee Lee, MD

Division of Cardiology, Yeungnam University

Medical Center, 170, Hyeonchung-ro, Nam-gu,

Daegu 42415, Republic of Korea

Tel: +82-53-620-3313 Fax: +82-53-621-3310

E-mail: chanheebox@naver.com

\section{Management of Atrial Flutter}

\begin{abstract}
Atrial flutter is a macro-reentrant atrial arrhythmia characterized by regular atrial rate and constant $\mathrm{P}$-wave morphology. The atrial flutter is divided into typical and atypical types, according to whether reentrant circuit involves the cavotricuspid isthmus. This review summarizes the management of atrial flutter based on 2015 ACC/ AHA/HRS guideline.
\end{abstract}

Key Words: - Atrial Flutter - Cavotricuspid Isthmus -Catheter Ablation

\section{서론}

심방조동은 대회귀성(macro-reentrant) 심방빈맥의 가장 흔한 형태로서 하대정맥-삼첨판 협부(cavotricuspid isthmus, CTI) 의존 여부에 따라서 전형적(typical, CTI dependent), 비전형적(atypical, nonisthmus dependent) 심방조동으로 나뉜다. ${ }^{1}$

\section{협부 의존성 심방조동}

협부 의존성 심방조동(CTI dependent atrial flutter)은 우심방에서 형성된 회귀성 율동으로 좌전사위(left anterior oblique [LAO] view)를 기준으로 삼첨판륜을 따라 반시계 방향의 회귀 회로(reentrant circuit)를 형성할 때(up the septum and down the free wall) 전형적(typical)
심방조동이라고 부르고, 드물지만 시계 방향의 회귀 회로를 형성할 때 역 전형적(reverse typical) 심방조동이라 부른다. ${ }^{2}$

심방조동은 심방세동과 유사한 임상 상황에서 일어나는 경우가 많으며, 한 환자가 심방세동과 심방조동을 함께 가지고 있는 경우가 흔하다. CTI 전극도자절제술 시행 후 14-30개월의 추적 관찰 기간 동안 22-50\%의 환자에서 심방세동이 발생한다고 보고되고 있다. 심방조동의 전극도자절제술 이후 심방세동이 발생할 수 있는 위험인자로는 기존의 심방세동, 좌심실 기능 저하, 구조적 또는 허혈성 심질환, 유도성(inducible) 심방세동, 좌심방 크기 증가가 있다. ${ }^{3}$

심방세동에서 항부정맥제(flecainide, propafenone, amiodarone)를 사용하는 경우에도 심방조동이 생길 수 있으며, 이 경우 반복적인 조동을 막기 위해서 협부 의존성 심방조동을 도자절제하는 것이 필요하다. ${ }^{4}$ 또한, 심방조동 
환자는 심방세동과 동일한 혈색전 위험도를 가지는 것으로 여겨져 심방세동과 동일한 정도의 항응고 치료가 필요하다. ${ }^{1}$

\section{협부 비의존성 심방조동}

협부 비의존성 심방조동(nonisthmus dependent atrial flutter)은 협부를 통한 전도와 관계 없이 발생하는 대회귀성 빈맥이며, 비전형적 심방조동으로도 불린다. 협부 비의존성 심방조동은 심장 수술이나 심방세동의 도자절제술 이후의 심방 반흔 형성(atrial scarring), 특발성으로 형성된 심방 일부의 섬유화 혹은 해부학적이거나 기능적인 전도 장애물에 의해 발생한다.5, 대표적으로 좌측 폐정맥 부위 도자절제술 후 좌측 하부 폐정맥과 승모판륜 사이에 느린 전도로가 형성되어 승모판륜을 따라 회귀하는 perimitral flutter과 좌측과 우측 폐정맥 선형 절제 후 그 사이의 협곡을 통해 좌심방의 지붕 (roof)을 따라 회귀하는 roof dependent flutter가 흔히 발생한다. 심방세동 도자절제술 이후 약 $5 \%$ 에서 소회귀성 (micro-reentrant) 또는 대회귀성(macro-reentrant) 좌심방 빈맥이 발생한다. ${ }^{7}$ 폐정맥 고립(pulmonary vein isolation)만 시행한 경우 이런 부정맥은 드물지만, 심방세동의 유병 기간이 길수록, 좌심방이 클수록, 선형 절제를 한 경우일수록 더 흔하게 발견된다. ${ }^{8}$

협부 의존성 심방조동에 비해 협부 비의존성 심방조동의
도자절제술은 좀 더 광범위한 매핑(mapping)이 필요하며, 성공률 또한 낮다. 회귀로의 위치에 따라 도자절제술의 접근법과 위험도가 달라진다. 또한, 국소성 심방빈맥(focal atrial tachycardia)뿐만 아니라 단일 고리(loop) 또는 이중 고리 회귀 회로가 존재할 수도 있다. 따라서 매핑과 도자절제술 전에 과거 심방 절개 및 도자절제술에 대한 기록을 확인하는 것이 도움이 된다.

모든 형태의 심방조동에서와 같이 심방세동의 도자절제술 후 발생한 협부 비의존성 조동은 절제술 이전의 심방세동보다 심박동수를 조절하기가 더욱 어렵다. 심박동수 조절을 위한 통상적인 투약에도 심박동수 조절이 안되면 약물이나 전기적 심율동전환을 이용한 동리듬으로의 전환이 필요할 수도 있다. 하지만 도자절제술이나 심장 수술 후 첫 3개월 동안에는 심방조동이 흔히 발견되기 때문에 심방조동에 대한 도자절제술은 3 개월 이후에 고려하는 것이 좋다. ${ }^{9}$

\section{심방조동의 급성기 치료}

2015년 ACC/AHA/HRS (American College of Cardiology/ American Heart Association/Heart Rhythm Society) 급성기 치료 권고 지침은 Figure 1과 같다. ${ }^{10}$

\section{Class of recommendation I}

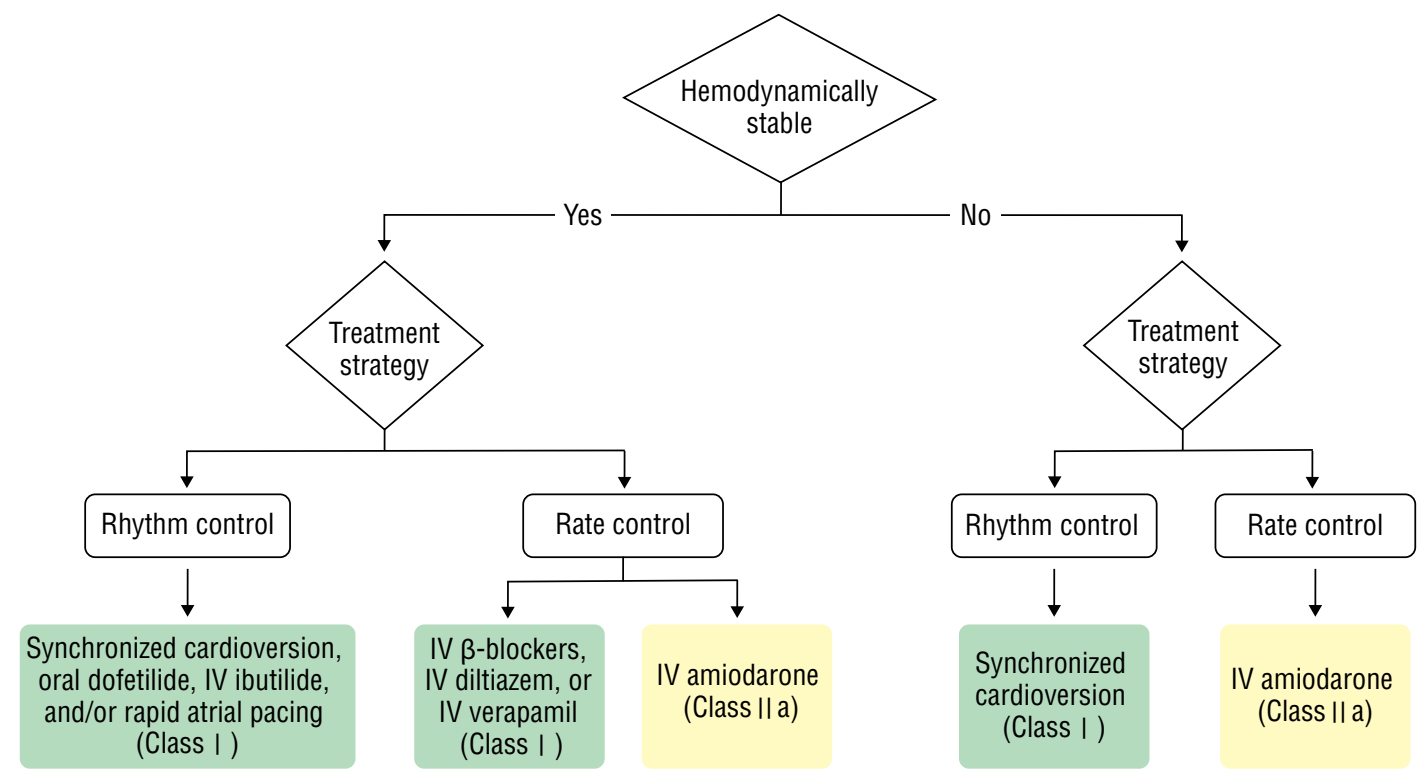

Figure 1. Acute treatment of atrial flutter. IV, intravenous. 
1) 경구 dofetilide 또는 ibutilide 정주는 심방조동의 급성기 약물학적 심율동전환에 유용하다(Level of Evidence A). 약물을 통한 심율동전환은 일반적으로 동기화된 전기적 심율동전환에 비해 효과적이지 못하고 부정맥 발생의 위험성이 있으나, 진정 치료가 불가능한 경우나 환자가 원하는 경우에 선택 사항이 될 수 있다.

2) 정주 또는 경구 베타차단제, diltiazem, verapamil은 혈역학적으로 안정된 경우 급성기 심박동수 조절에 유용하다(B-R).

칼슘차단제 정주 요법 중에서는 안전성과 효과 면에서 diltiazem이 더 좋다. Verapamil, diltiazem은 심장 차단이나 동기능 부전이 있는 진행성 심부전 환자나 조기흥분(preexcitation) 환자에게 사용해서는 안 된다.

베타차단제의 심박동수 저하 효과는 교감신경계 활성을 줄이는 것과 관련이 있다. Esmolol이 효과가 빨라서 일반적으로 선호된다. 베타차단제는 비대상성 심부전이나 반응성 기도 질환 환자에서 사용해서는 안 된다.

3) 계획적(elective) 동기화 전기적 심율동전환술은 안정된 심방조동 환자에서 리듬 조절을 하고자 할 때 선택한다 (B-NR)

심방세동과 동일한 정도의 항응고요법이 필요하다. 동리듬으로 회복이 되면 빈맥 매개성 심근병증 (tachycardia mediated cardiomyopathy)으로의 진행을 막을 수 있다.

4) 혈역학적으로 불안정한 경우나 약물 치료에 반응이 없는 경우 동기화된 전기적 심율동전환술이 필요하다(B-NR)

5) 빠른 심방 조율(rapid atrial pacing)을 통한 급성기 심율동전환은 영구형 심박동기나 제세동기를 가지고 있는 경우나 심장 수술 이후 일시적 심방 조율을 하는 경우에 유용하다(C-LD).

빠른 심방 조율을 통해서 심방세동이 유발된 경우에 심박동수 조절이 더욱 잘되며, 순차적으로 동리듬으로 바뀔 수도 있다.

6) 심방세동과 동일한 정도의 급성기 항혈전 치료가 권고된다
(B-NR).

메타분석에서 심방조동의 심율동전환 이후 단기간 뇌졸중 발생률은 0-7\%였으며, 지속적인 심방조동을 가진 환자의 혈색전증 발생률은 연간 평균 $3 \%$ 였다.

\section{Class of recommendation Ila}

1) Amiodarone 정주 요법은 수축기 심부전이 있는 심방조동 환자의 급성기 심실박동 조절(심실 조기흥분이 없는 경우) 에 유용할 수 있다(B-R).

\section{심방조동의 유지 치료}

2015년 ACC/AHA/HRS 유지 치료 권고 지침은 Figure 2와 같다. ${ }^{10}$

\section{Class of recommendation I}

1)증상이 있거나 약물 치료에 반응이 없는 환자에서 CTI 도자절제술이 권고된다(B-R).

삼첨판륜과 하대정맥 사이의 절제선이 회귀 회로 차단에 효과적이기 때문에 CTI가 도자절제의 목표가 된다.

2)혈역학적으로 안정된 경우 베타차단제, diltiazem, verapamil이 심박동수 조절에 유용하다(C-LD).

일반적으로 심부전이 있는 환자에서 베타차단제가 선호된다. 심실 박동수가 빨라지면서 심실세동으로 변성 (degeneration)될 수 있기 때문에 조기흥분성 심방조동에서는 베타차단제, diltiazem, verapamil을 투여해서는 안 된다.

3) 적어도 1 종의 항부정맥제를 사용한 이후에도 증상이 있는 재발성 협부 비의존성 심방조동에서 도자절제술은 유용하다.

이전 수술이나 도자절제술의 접근법에 대한 정보와 빈맥에 대한 세밀화된 활성(activation) 및 동조화 (entrainment) 매핑이 유용하다.

4) 심방세동과 동일한 수준의 항혈전 유지 치료가 권고된다. 


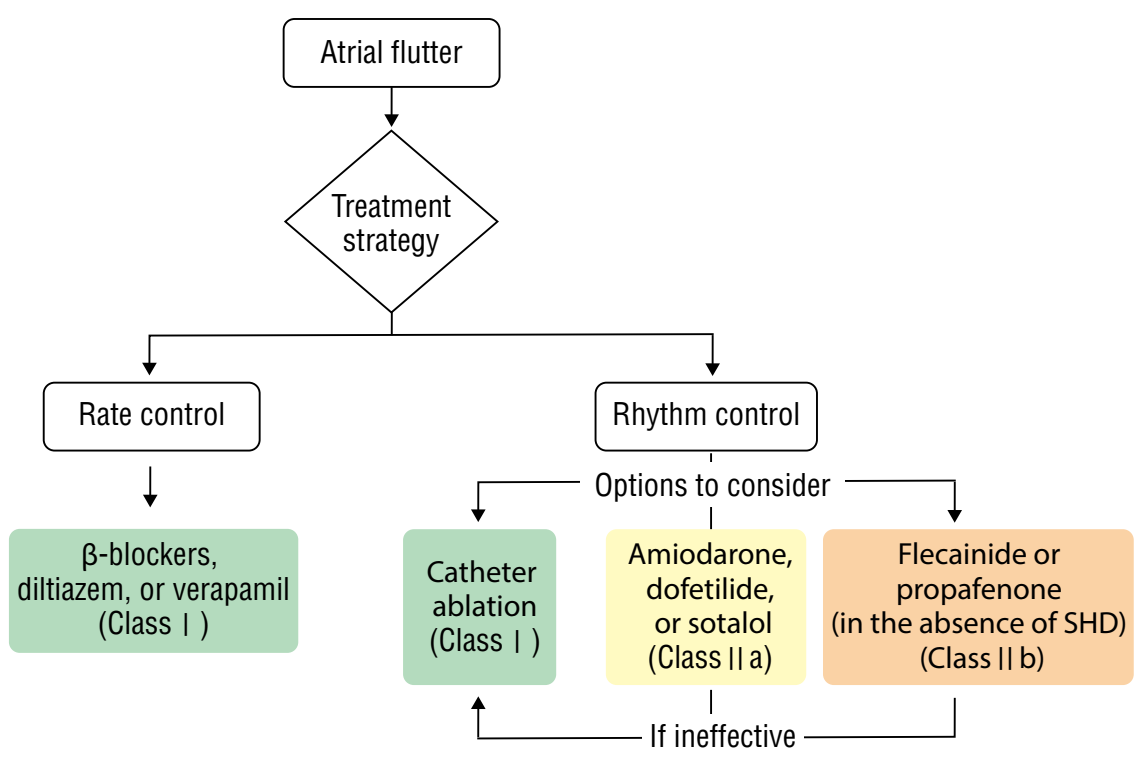

Figure 2. Ongoing treatment of atrial flutter.

SHD, structural heart disease (inducing ischemic heart disease).

\section{Class of recommendation Ila}

1)증상이 있는 재발성 심방조동에서 동성 리듬을 유지하기 위해 다음과 같은 약물이 유용할 수 있으며, 이는 기존의 심질환과 동반 질환에 따라서 선택해야 한다(B-R).

(1) Amidorone - 명확한 독성 때문에 다른 치료가 금기이거나 효과가 없을 때만 사용한다.

(2) Defetilide - QT 간격과 신기능 변화에 대한 주의 깊은 관찰이 필요하다.

(3) Sotalol - Class III 항부정맥제로 피로나 서맥과 같은 베타차단제의 부작용과 관련 있다.

2) 심방세동에서 flecainide, propafenone, amiodarone 사용 후 발생한 협부 의존성 심방조동에서 도자절제술은 합당하다(B-NR).

3) 임상적 또는 유도성 협부 의존성 심방조동의 병력이 있는 환자에서 심방세동 전극도자절제술 시 CTI를 함께 절제하는 것은 합당하다 $(\mathrm{C}-\mathrm{LD})$.
4)치료 선택에 대한 잠재적 위험도 및 이득을 고려한 후 증상이 있는 재발성 협부 비의존성 심방조동에서 항부정맥제를 사용하기 전 첫 번째 치료로 도자절제술이 합당하다(C-LD).

\section{Class of recommendation Illb}

1)증상이 있는 재발성 심방조동에서 구조적 또는 허혈성 심질환이 없다면 동리듬 유지하는 데 flecainide 또는 propafenone을 고려해볼 수 있다(B-R).

심방의 전도 속도가 늦어져 심방 박동수는 늦어지지만, 1:1 방실 전도가 되면서 심실 박동수가 오히려 증가할 위험성이 있다. 따라서 방실 전도를 느리게 하는 베타차단제와 verapamil, diltiazem과 같은 칼슘차단제를 병용해야 한다.

2) 증상이 없는 재발성 심방조동에서 도자절제술은 합당할 수 있다(C-LD).

심방조동에서 도자절제술은 매우 유용하며, 한 번의 시술로도 성공률이 $90 \%$ 이상이다. 약물 치료보다 동리듬을 오래 유지하는 데 더욱 효과적이며, 빈맥 매개 심근병증의 잠재적 위험을 피할 수 있다. 


\section{결론}

본 종설을 통해 심방조동에 대한 2015년 ACC/AHA/HRS 권고 치침을 정리해 보았다. 심방조동 환자를 접할 때 항상 심방세동을 함께 가지고 있을 가능성을 염두에 두며, 심방세동과 동일한 정도의 항혈전 치료가 필요함을 잊지 말아야 한다.

\section{References}

1) January CT, Wann LS, Alpert JS, Calkins H, Cigarroa JE, Cleveland JC Jr., Conti JB, Ellinor PT, Ezekowitz MD, Field ME, Murray KT, Sacco RL, Stevenson WG, Tchou PJ, Tracy CM, Yancy CW, American College of Cardiology/American Heart Association Task Force on Practice G. 2014 AHA/ACC/HRS guideline for the management of patients with atrial fibrillation: a report of the American College of Cardiology/American Heart Association task force on practice guidelines and the Heart Rhythm Society. J Am Coll Cardiol. 2014;64:e1-e76.

2) Saoudi N, Cosio F, Waldo A, Chen SA, Iesaka Y, Lesh M, Saksena S, Salerno J, Schoels W; Working Group of Arrhythmias of the European of C, the North American Society of P, Electrophysiology. A classification of atrial flutter and regular atrial tachycardia according to electrophysiological mechanisms and anatomical bases; a statement from a Joint Expert Group from the Working Group of arrhythmias of the European Society of Cardiology and the North American Society of Pacing and Electrophysiology. Eur Heart J. 2001;22:1162-1182.

3) Ellis K, Wazni O, Marrouche N, Martin D, Gillinov M, McCarthy P, Saad EB, Bhargava M, Schweikert R, Saliba W, Bash D, Rossillo A, Erciyes D, Tchou P, Natale A. Incidence of atrial fibrillation postcavotricuspid isthmus ablation in patients with typical atrial flutter: left-atrial size as an independent predictor of atrial fibrillation recurrence. J Cardiovasc Electrophysiol. 2007;18:799-802.

4) Bertaglia E, Bonso A, Zoppo F, Proclemer A, Verlato R, Coro L, Mantovan R, Themistoclakis S, Raviele A, Pascotto P, NorthEastern Italian Study on Atrial Flutter Ablation I. Different clinical courses and predictors of atrial fibrillation occurrence after transisthmic ablation in patients with preablation lone atrial flutter, coexistent atrial fibrillation, and drug induced atrial flutter. Pacing Clin Electrophysiol. 2004;27:1507-1512.
5) Baker BM, Lindsay BD, Bromberg BI, Frazier DW, Cain ME, Smith JM. Catheter ablation of clinical intraatrial reentrant tachycardias resulting from previous atrial surgery: localizing and transecting the critical isthmus. J Am Coll Cardiol. 1996;28:411417.

6) Jais P, Shah DC, Haissaguerre M, Hocini M, Peng JT, Takahashi A, Garrigue S, Le Metayer P, Clementy J. Mapping and ablation of left atrial flutters. Circulation. 2000;101:2928-2934.

7) Chugh A, Oral H, Lemola K, Hall B, Cheung P, Good E, Tamirisa K, Han J, Bogun F, Pelosi F, Jr., Morady F. Prevalence, mechanisms, and clinical significance of macroreentrant atrial tachycardia during and following left atrial ablation for atrial fibrillation. Heart Rhythm. 2005;2:464-471.

8) Veenhuyzen GD, Knecht S, O'Neill MD, Phil D, Wright M, Nault I, Weerasooriya R, Miyazaki S, Sacher F, Hocini M, Jais P, Haissaguerre M. Atrial tachycardias encountered during and after catheter ablation for atrial fibrillation: part I: classification, incidence, management. Pacing Clin Electrophysiol. 2009;32:393398.

9) Calkins H, Kuck KH, Cappato R, Brugada J, Camm AJ, Chen SA, Crijns HJ, Damiano RJ, Jr., Davies DW, DiMarco J, Edgerton J, Ellenbogen K, Ezekowitz MD, Haines DE, Haissaguerre M, Hindricks G, Iesaka Y, Jackman W, Jalife J, Jais P, Kalman J, Keane D, Kim YH, Kirchhof P, Klein G, Kottkamp H, Kumagai K, Lindsay BD, Mansour M, Marchlinski FE, McCarthy PM, Mont JL, Morady F, Nademanee K, Nakagawa H, Natale A, Nattel S, Packer DL, Pappone C, Prystowsky E, Raviele A, Reddy V, Ruskin JN, Shemin RJ, Tsao HM, Wilber D, Heart Rhythm Society Task Force on C, Surgical Ablation of Atrial F. 2012 HRS/EHRA/ ECAS expert consensus statement on catheter and surgical ablation of atrial fibrillation: recommendations for patient selection, procedural techniques, patient management and follow-up, definitions, endpoints, and research trial design: a report of the Heart Rhythm Society (HRS) task force on catheter and surgical ablation of atrial fibrillation. Developed in partnership with the European Heart Rhythm Association (EHRA), a registered branch of the European Society of Cardiology (ESC) and the European Cardiac Arrhythmia Society (ECAS); and in collaboration with the American College of Cardiology (ACC), American Heart Association (AHA), the Asia Pacific Heart Rhythm Society (APHRS), and the Society of Thoracic Surgeons (STS). Endorsed by the governing bodies of the American College of Cardiology Foundation, the American Heart Association, the European 
Cardiac Arrhythmia Society, the European Heart Rhythm Association, the Society of Thoracic Surgeons, the Asia Pacific Heart Rhythm Society, and the Heart Rhythm Society. Heart Rhythm. 2012;9:632-696.e621.

10) Page RL, Joglar JA, Caldwell MA, Calkins H, Conti JB, Deal BJ, Estes NA, 3rd, Field ME, Goldberger ZD, Hammill SC, Indik JH,
Lindsay BD, Olshansky B, Russo AM, Shen WK, Tracy CM, Al-Khatib SM. 2015 ACC/AHA/HRS guideline for the management of adult patients with supraventricular tachycardia: a report of the American College of Cardiology/American Heart Association task force on clinical practice guidelines and the Heart Rhythm Society. J Am Coll Cardiol. 2016;67:e27-e115. 